\title{
Histologia da embriogênese somática induzida em embriões de sementes maduras de Urochloa brizantha apomítica
}

\author{
Sandra Janeth Lenis-Manzano(1), Ana Claudia Guerra de Araujo(2), Cacilda Borges do Valle(3), \\ Eliana de Fátima Santana( ${ }^{(2)}$ e Vera Tavares de Campos Carneiro(2)
}

\begin{abstract}
(1)Universidade de Brasília, Departamento de Biologia Celular, Campus Universitário Darcy Ribeiro, Asa Norte, Universidade de Brasília, CEP 70910-900 Brasília, DF. E-mail: slenis20@hotmail.com (2)Embrapa Recursos Genéticos e Biotecnologia, PqEB, Avenida W5 Norte (Final), Caixa Postal 02372, CEP 70770-917 Brasília, DF. E-mail: vera@cenargen.embrapa.br, guerra@cenargen.embrapa.br, santana@cenargen.embrapa.br (3)Embrapa Gado de Corte, BR 262, Km 4, Caixa Postal 154, CEP 79002-970 Campo Grande, MS. E-mail: cacilda@cenargen.embrapa.br
\end{abstract}

Resumo - O objetivo deste trabalho foi descrever o processo de embriogênese somática em Urochloa brizantha cv. Marandu (Syn. Brachiaria brizantha cv. Marandu) e fornecer subsídios para o aprimoramento dos métodos de cultura de tecidos e transformação genética. Calos embriogênicos foram obtidos por indução em embriões isolados de sementes maduras, e cultivados in vitro, em meio de cultura que continha ácido 2,4-diclorofenoxiacético, 6-benzilaminopurina e caseína hidrolisada. Plântulas foram regeneradas a partir dos calos embriogênicos, na presença de ácido naftalenoacético e cinetina. Esse processo foi descrito morfologicamente por observações em microscopia de luz de secções seriadas semifinas de tecidos fixados, ao longo do processo de regeneração, em FAA [formaldeído (40\%): ácido acético glacial: etanol (50\%), a 5:5:90 $\mathrm{v} / \mathrm{v} / \mathrm{v}]$. Os embriões das sementes de $U$. brizantha $\mathrm{cv}$. Marandu não têm epiblasto e são classificados como do tipo panicoide. Nas condições estabelecidas de cultura in vitro, calos embriogênicos e embriões somáticos de $U$. brizantha cv. Marandu, desenvolvem-se a partir de células meristemáticas do escutelo.

Termos para indexação: Brachiaria, cultura de tecidos, melhoramento de forrageiras, regeneração, transformação genética.

\section{Histology of somatic embryogenesis induced in embryos of mature seeds of the apomictic Urochloa brizantha}

\begin{abstract}
The objective of this work was to describe the process of somatic embryogenesis in Urochloa brizantha $\mathrm{cv}$. Marandu (Syn. Brachiaria brizantha cv. Marandu) and to provide support for the improvement of tissue culture and genetic transformation methods. Embryogenic calli were obtained by induction in embryos isolated from mature seeds, and cultivated in vitro in culture medium containing 2,4-dichlorophenoxyacetic acid, 6-benzylaminopurine and hydrolyzed casein. Plantlets were regenerated from the embryogenic calli in the presence of naphthaleneacetic acid and kinetin. This process was described by morphological observations of serial semithin sections of tissues fixed along the regeneration process in FAA ( $40 \%$ formaldehyde: acetic acid: $50 \%$ ethanol, at 5:5:90 v/v/v), using light microscopy. Seed embryos of $U$. brizantha cv. Marandu do not have epiblast and are classified as Panicum-type. Under in vitro culture conditions, embryogenic calli and somatic embryos of $U$. brizantha $\mathrm{cv}$. Marandu develop from meristematic cells of the scutellum.
\end{abstract}

Index terms: Brachiaria, tissue culture, forage breeding, regeneration, genetic transformation.

\section{Introdução}

O gênero Brachiaria apresenta importantes espécies forrageiras que se adaptam a variadas condições de solos e destacam-se em solos ácidos e fracos (Araújo et al., 2008). Esse gênero da família Poaceae foi trazido da África para o Brasil; sua área cultivada é estimada em 40 milhões de hectares somente no Cerrado. As principais espécies desse gênero participam com $87 \%$ das sementes comercializadas no Brasil, das quais as mais importantes são: $B$. brizantha, $B$. decumbens, $B$. humidicola e $B$. ruziziensis (binômios sinomizados em Urochloa brizantha, U. humidicola, U. decumbens; Karia et al., 2006).

No Brasil, as pastagens com braquiárias alimentam um rebanho de 170 milhões de cabeças de gado (Instituto Brasileiro de Geografia e Estatística, 2006) e são constituídas principalmente por duas cultivares apomíticas: B. brizantha cv. Marandu e B. decumbens $\mathrm{cv}$. Basilisk (Valle et al., 2004). A cultivar Marandu foi liberada pela Embrapa em 1983, para atender a demanda por cultivares resistentes à cigarrinha-das-pastagens, e é hoje o capim mais plantado no Brasil (Araújo et al., 2008). A progênie resultante da reprodução apomítica

Pesq. agropec. bras., Brasília, v.45, n.5, p.435-441, maio 2010 
é constituída por clones idênticos à planta-mãe (Ozias-Akins, 2006; Tucker \& Koltunow, 2009), o que implica baixa diversidade genética. As únicas fontes de diversidade dessa população apomítica facultativa são mutações somáticas ou ocorrência de fecundação nos sacos embrionários do tipo Polygonum, característicos de plantas sexuais. No caso de $B$. brizantha cv. Marandu, 2\% dos sacos embrionários são deste tipo, enquanto os demais são do tipo Panicum, característicos de apomíticos apospóricos (Araujo et al., 2000). Como consequência, alterações ambientais ou doenças podem danificar drasticamente a população, cuja adaptação a mudanças baseia-se em eventos de rara ocorrência. Assim, a baixa variabilidade genética das pastagens brasileiras, constituídas principalmente de plantas apomíticas, torna-as mais vulneráveis a doenças e pragas.

A apomixia em Brachiaria é classificada como apospórica pseudogâmica, ou seja, a polinização é necessária para a fertilização do núcleo polar e a formação do endosperma. O embrião, no entanto, desenvolve-se de modo autônomo, diretamente da oosfera não reduzida (Araujo et al., 2000; Alves et al., 2001). A viabilidade dos grãos de pólen das plantas apomíticas permite que elas sejam usadas para fecundação de plantas sexuais, em programas de melhoramento. No entanto, diferenças de ploidia entre as plantas sexuais (diploides) e apomíticas (poliploides) dificultam a obtenção de novas combinações gênicas (Valle et al., 2004). Estudos vêm sendo realizados na cultura in vitro de células e tecidos de braquiária, para duplicação de plantas sexuais por aplicação de colchicina (Pinheiro et al., 2000; Araujo et al., 2005). Além disso, atualmente pode-se recorrer a estratégias de engenharia genética para incorporar características de interesse presentes no pool gênico do gênero ou da natureza de modo geral (Carneiro \& Dusi 2002; Valle et al., 2004). Além do isolamento e caracterização de genes de interesse, a engenharia genética de plantas requer o estabelecimento prévio de técnicas de cultura in vitro, para a implementação de técnicas de transformação genética.

O método de regeneração de Brachiaria spp. por embriogênese somática (Tohme et al., 1996) foi desenvolvido para, posteriormente, estabelecer-se a técnica de transformação por biobalística (Lenis-Manzano, 1998). Essa técnica tem sido aprimorada em diferentes aspectos, como determinação dos melhores vetores para transformação (Silveira et al., 2003), alterações em meios de cultivo (Silveira et al., 2003; Cabral et al., 2006; Oliveira et al., 2008) e ampliação da gama de explantes iniciais da cultura in vitro (Pinheiro et al., 2000; Cabral et al., 2008). A importância do conhecimento do processo de desenvolvimento de embriões somáticos está em contribuir para o aperfeiçoamento das técnicas de cultura de tecidos e para o estabelecimento de parâmetros físicos da transformação por biobalística, como posicionamento dos explantes nas placas de Petri e direcionamento dos tiros.

O objetivo do presente trabalho foi descrever morfologicamente $\mathrm{o}$ processo de embriogênese somática de $U$. brizantha, estabelecido a partir da cultura in vitro de embriões extraídos de sementes maduras de $U$. brizantha cv. Marandu.

\section{Material e Métodos}

Foram usadas sementes do genótipo $U$. brizantha $\mathrm{cv}$. Marandu apomítica tetraploide $(2 \mathrm{n}=4 \mathrm{x}=36)$, código de registro BRA 000591 no Banco Ativo de Germoplasma de Brachiaria da Embrapa Gado de Corte, Campo Grande, MS. Este trabalho utiliza o nome veiculado na Lista de Espécies da Flora do Brasil (Shirasuna, 2010). As sementes (Figura 1) escarificadas foram desinfestadas por imersão em etanol $70 \%(\mathrm{v} / \mathrm{v})$, por $2 \mathrm{~min}$, e hipoclorito de sódio $2,5 \%(\mathrm{v} / \mathrm{v})$, por $15 \mathrm{~min}$, seguida de quatro a cinco lavagens em água bidestilada autoclavada. As sementes foram mantidas por $20 \mathrm{~min}$ em água estéril. Os embriões (Figura 1) foram extraídos e dispostos em placas de Petri (60x15 mm) com $15 \mathrm{~mL}$ de meio de indução de calos M1.

Foram utilizados, para a cultura de tecidos, os seguintes meios: de indução de calos M1 - sais de MS (Murashige \& Skoog, 1962), 2 mg de 2,4-D (ácido 2,4 dicloro-fenoxiacético), 0,2 mg de BAP (6-benzilaminopurina), $100 \mathrm{mg}$ de caseína hidrolisada, $30 \mathrm{~g}$ de sacarose, 6,5 g de Phytagel em $1 \mathrm{~L}$ de água bidestilada, pH 5,7; e de regeneração - sais de MS (Murashige \& Skoog, 1962), $5 \mathrm{~mL}$ de vitaminas de MS 100 x, $10 \mathrm{mg}$ de inositol, 0,1 mg de ANA (ácido naftaleno acético), 0,4 $\mathrm{mg}$ de KIN (cinetina), $30 \mathrm{~g}$ de sacarose, $5 \mathrm{~g}$ de Phytagel em $1 \mathrm{~L}$ de água bidestilada, $\mathrm{pH} 5,7$. O Phytagel foi acrescentado após ajuste de $\mathrm{pH}$. Os meios foram distribuídos em frascos de Erlenmeyer $(500 \mathrm{~mL}$ em frascos de $1 \mathrm{~L})$ e autoclavados a $120^{\circ} \mathrm{C}$ e 
$15.000 \mathrm{lbs} \mathrm{pol}^{-2}$ de pressão, por $15 \mathrm{~min}$ e, em seguida, distribuídos em placas de Petri (Lenis-Manzano, 1998).

Para a indução de calos, os explantes permaneceram a $27^{\circ} \mathrm{C}$, por 20-30 dias, em meio M1, na ausência de luz. À medida que os calos embriogênicos formavam-se, eles eram separados delicadamente do embrião maduro e dos calos friáveis. Os calos embriogênicos foram transferidos para o meio de regeneração e mantidos a $27^{\circ} \mathrm{C}$ sob fotoperíodo de 16 horas, com uso de lâmpadas fluorescentes. Após duas semanas, as plântulas regeneradas com 7-10 cm de comprimento foram transplantas para sacos de plástico, com terra previamente autoclavada, e mantidas em casa de vegetação da Embrapa Recursos Genéticos e Biotecnologia, Brasília, DF.

Em diferentes momentos do cultivo in vitro, os embriões de $U$. brizantha cv. Marandu e os calos derivados foram processados, para análises morfológicas em microscopia de luz. As coletas foram realizadas no momento do isolamento do embrião após $3,5,7,14,20,25$ e 30 dias de cultivo. As amostras foram incubadas em solução de FAA [formaldeído (40\%): ácido acético glacial: etanol $(50 \%)$, a 5:5:90 v/v/v] a $4^{\circ} \mathrm{C}$, por 24 horas, desidratadas em concentrações crescentes de etanol (50, 70, 90 e $100 \%$ ), por $15 \mathrm{~min}$ em cada solução, e 1 hora em etanol 100\%, clarificadas em xilol e incluídas em Paraplast X-Tra Tissue Embedding Medium (McCormick Scientific, St. Louis, EUA).

Secções seriadas semifinas (6 $\mu \mathrm{m}$ de espessura) foram obtidas em micrótomo Leica (Microsystems GmbH, Wetzlar, Alemanha) e montadas em lâminas histológicas recobertas com lisina. Após remoção do Paraplast, as secções foram coradas com safranina a $2 \%$ e solução etanólica de verde rápido a $2 \%$. Para cada etapa de coleta de amostras, foram preparadas 30 lâminas. As secções foram analisadas e documentadas em microscópio de luz Zeiss Axiophot (Carl Zeiss MicroImaging GmbH, Jena, Alemanha).

\section{Resultados e Discussão}

Embriões de sementes maduras de $U$. brizantha $\mathrm{cv}$. Marandu (Figura 1), em meio M1, após uma semana de cultura no escuro, produziram massa de calos translúcidos e sem poder regenerativo: os calos friáveis (Figura 2 A). Uma a duas semanas depois, os embriões desenvolveram estruturas brancas (calos embriogênicos), compactas e com poder regenerativo
(Figura 2 B). Os calos foram transferidos para o meio de regeneração. Após uma semana, os embriões desenvolveram-se em plântulas completas (Figura 2 C).

A frequência de formação de calos embriogênicos, em relação ao número de embriões com inoculação,
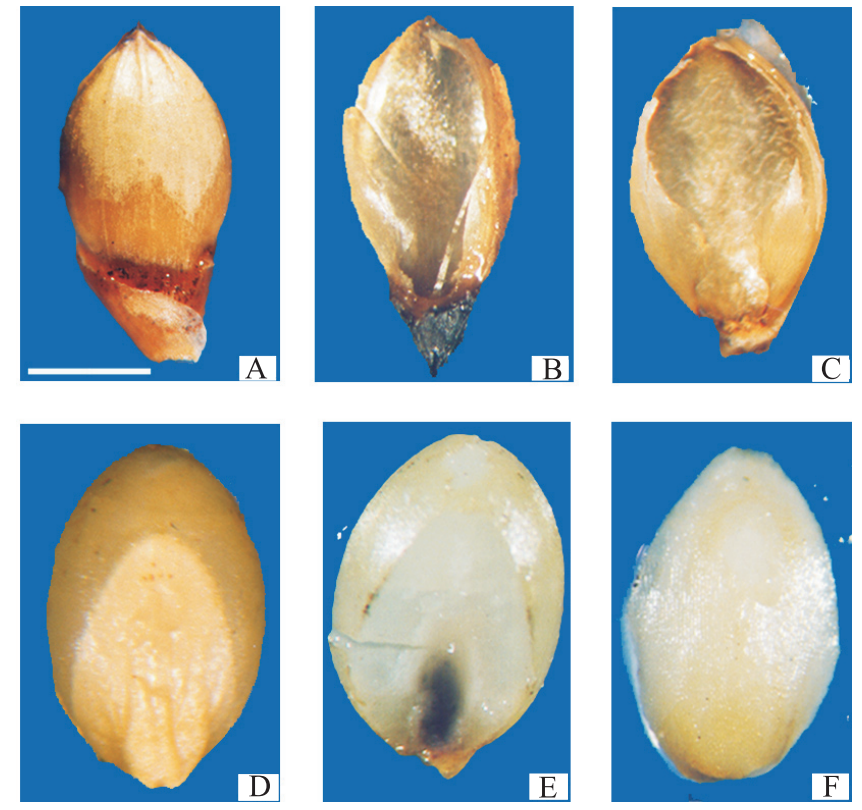

Figura 1. Etapas do isolamento de embrião de semente madura de Urochloa brizantha cv. Marandu: A, semente; B e C, glumas extraídas das sementes, antes da desinfestação; $\mathrm{D}$, semente inteira após escarificação; E, endosperma; $\mathrm{F}$, embrião isolado após desinfestação e 20 min de imersão em água. Barras em A, B, C correspondem a $250 \mu \mathrm{m}$ e, em D, E, F, a $400 \mu \mathrm{m}$.

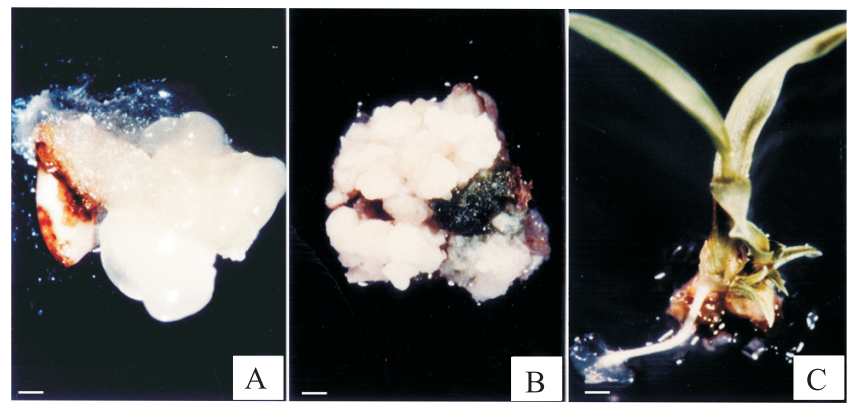

Figura 2. Processo de indução de calos e regeneração em plantas de Urochloa brizantha cv. Marandu: A, calo formado em embrião maduro cultivado em meio M1 por dez dias (barra corresponde a 0,5 mm); B, calo embriogênico formado após transferência do calo mostrado em A para meio de regeneração, após três semanas de cultura (barra corresponde a $0,8 \mathrm{~mm})$; $\mathrm{C}$, planta completa, regenerada a partir de embrião somático (barra corresponde a $4 \mathrm{~cm}$ ). 
foi de $76 \%$, o que é similar às obtidas com outras espécies, nas mesmas condições de indução de calos. O papel fundamental do 2,4-D para a indução de calos foi observado em diferentes monocotiledôneas (Tohme et al., 1996; Lenis-Manzano, 1998; Lamb et al., 2002; Jimenez, 2005; Vasil, 2005; Campos et al., 2009). Neste trabalho, o papel dos reguladores de crescimento na proliferação, manutenção e diferenciação dos calos, em cultura de tecidos de U. brizantha, seguiu o padrão descrito anteriormente em outras espécies: alto conteúdo de auxina e baixo de cinetinas para a produção de calos; baixa ou nenhuma quantidade de auxina; e aumento de cinetinas para a regeneração e obtenção de brotos.

A eficiência da embriogênese somática depende da capacidade de morfogênese do explante colocado em cultura. Em sementes completas das mesmas espécies, Tohme et al. (1996) observaram que a eficiência chega a um máximo de $65 \%$, mas sugeriram que melhor resposta poderia ser obtida em embriões isolados, como no presente trabalho $(76 \%)$.

Os calos embriogênicos, fracionados entre $0,5 \mathrm{e}$ $1 \mathrm{~cm}^{2}$, formaram tantas plântulas quanto o número de calos colocados em meio de regeneração após quatro ou cinco semanas. Esses resultados são semelhantes aos de outras gramíneas (Lamb et al., 2002; Zhang et al., 2006; Yu et al., 2008; Campos et al., 2009), com as quais foi obtida regeneração eficiente de embriões maduros.

Foram constatados embriões do tipo panicoide, sem epiblasto (Figura $3 \mathrm{~A}$ ). Esses são os primeiros relatos de características histológicas de embriões de $U$. brizantha em cultivo in vitro. As alterações morfológicas iniciais foram observadas depois de três dias da colocação dos embriões em meio M1, como alongamento do embrião e proliferação celular nos tecidos adjacentes à porção interna do escutelo (Figura $3 \mathrm{~B}$ ). Divisões de células originárias do escutelo levaram à formação de calos friáveis (Figura 3 C, D). Observou-se, também, maior vacuolização e consequente aumento no volume das células, 5 a 7 dias após a colocação em meio de cultura M1 (Figura 3 C). Após 14 a 20 dias de cultivo, pequenos grupos de proembriões foram detectados na periferia do escutelo, e foi possível visualizar calos embriogênicos (Figuras 3 D, E). A formação de calos embriogênicos foi inicialmente detectada perto do procâmbio do escutelo e, posteriormente, em sua periferia, pela presença de proembriões. Os embriões somáticos desenvolvidos mostraram diferenciação do coleóptilo e ápice da raiz (Figura $3 \mathrm{~F}$ ) e, após três semanas, sistema vascular. Entre 20 e 30 dias de cultivo, embriões em diferentes estágios de desenvolvimento foram encontrados. O número e o volume de calos morfogênicos decresceram, e zonas meristemáticas com proliferação celular no interior dos calos foram detectadas (Figuras 2 A, B). Depois de duas semanas, as plântulas regeneradas de 7 a $10 \mathrm{~cm}$ de comprimento foram levadas à casa de vegetação (Figura $2 \mathrm{C}$ ). A embriogênese somática aconteceu entre três e quatro semanas após a colocação no meio de cultura, o que é considerado um período longo (Vasil \& Vasil, 1982).

Verificou-se que a posição apropriada para colocar embriões no meio de cultura deve ser mantendose o escutelo voltado para cima, e não em contato com o meio. Outros autores também verificaram que o posicionamento do explante no meio de cultura influencia a resposta de calos embriogênicos em Calotropis gigantea (Roy \& De, 1990).

Este trabalho demonstra que os embriões somáticos de $U$. brizantha, em meio de regeneração, têm origem em células provenientes do escutelo, assim como em outras gramíneas forrageiras (Botti \& Vasil, 1984; Lu \& Vasil, 1985). Após os primeiros dias da cultura em meio de indução de calos M1, as células meristemáticas ou células derivadas de tecidos, como o internó do escutelo ou tecidos próximos a ele no embrião, sofreram aumento do volume e intensa vacuolização (Figura 3). Do mesmo modo, O'Hara \& Street (1978), em trabalho pioneiro de morfologia em gramíneas, demonstraram que a formação de calos embriogênicos em trigo só inicia-se quando o explante contém células meristemáticas derivadas do internó. Esse crescimento celular é atribuído à rápida metabolização do 2,4-D, que leva ao espessamento das paredes celulares e à diferenciação irreversível em embriões somáticos (Vasil, 1988).

A determinação da origem das células formadoras dos calos embriogênicos em embriões, realizada no presente trabalho, poderá auxiliar no direcionamento do trabalho de cultura de tecidos com vistas ao aprimoramento do processo de transformação genética. Observou-se que a formação de calos embriogênicos e embriões somáticos inicia-se pela divisão celular no escutelo e amplia-se até sua periferia. Em trigo, foi observado que os embriões somáticos são formados em embriões imaturos, pela proliferação das camadas 
eptelial e subepitelial do escutelo (Vasil, 2007). As células embriogênicas de $U$. brizanha apresentam parede celular delgada, citoplasma denso e vacúolos numerosos e pequenos, e estão organizadas em pequenos pacotes compactos. Os embriões somáticos originam-se direta ou indiretamente de células individuais, perto do internó do escutelo, conforme descrito em diferentes cereais (Vasil, 1988). Em estudos realizados em cultivo
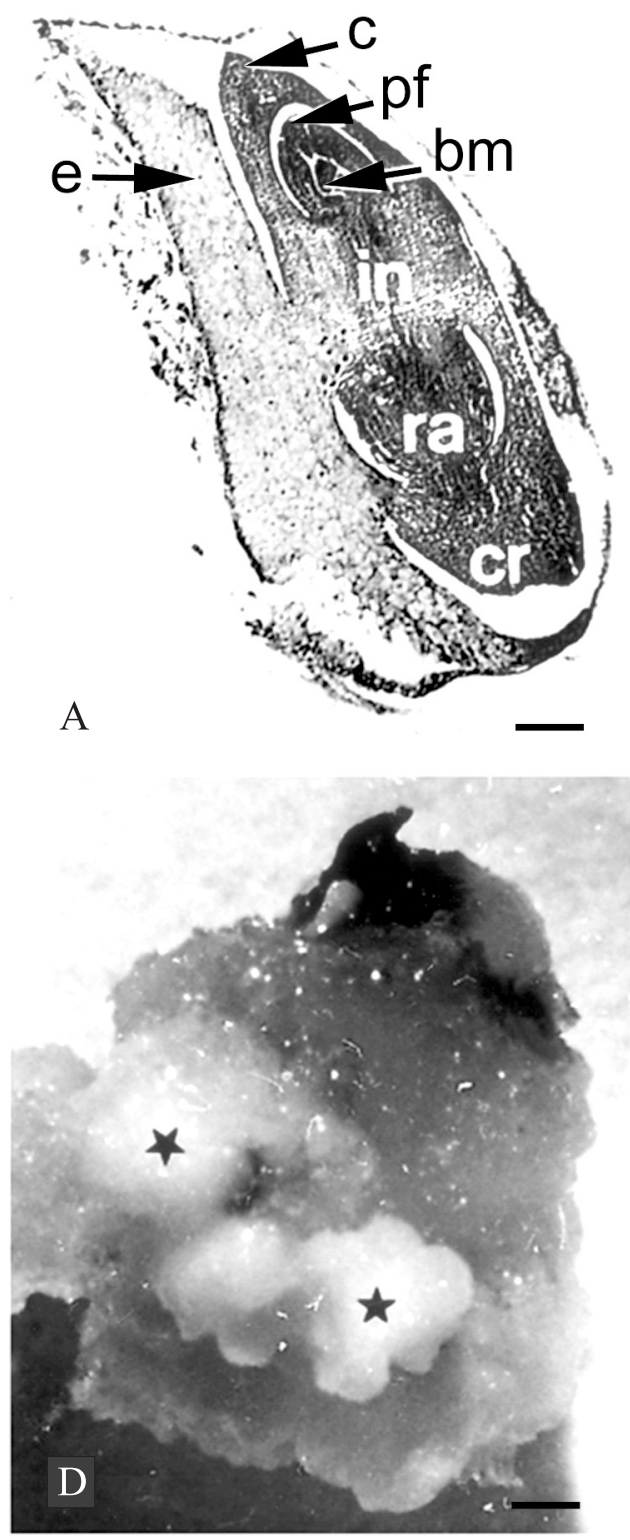
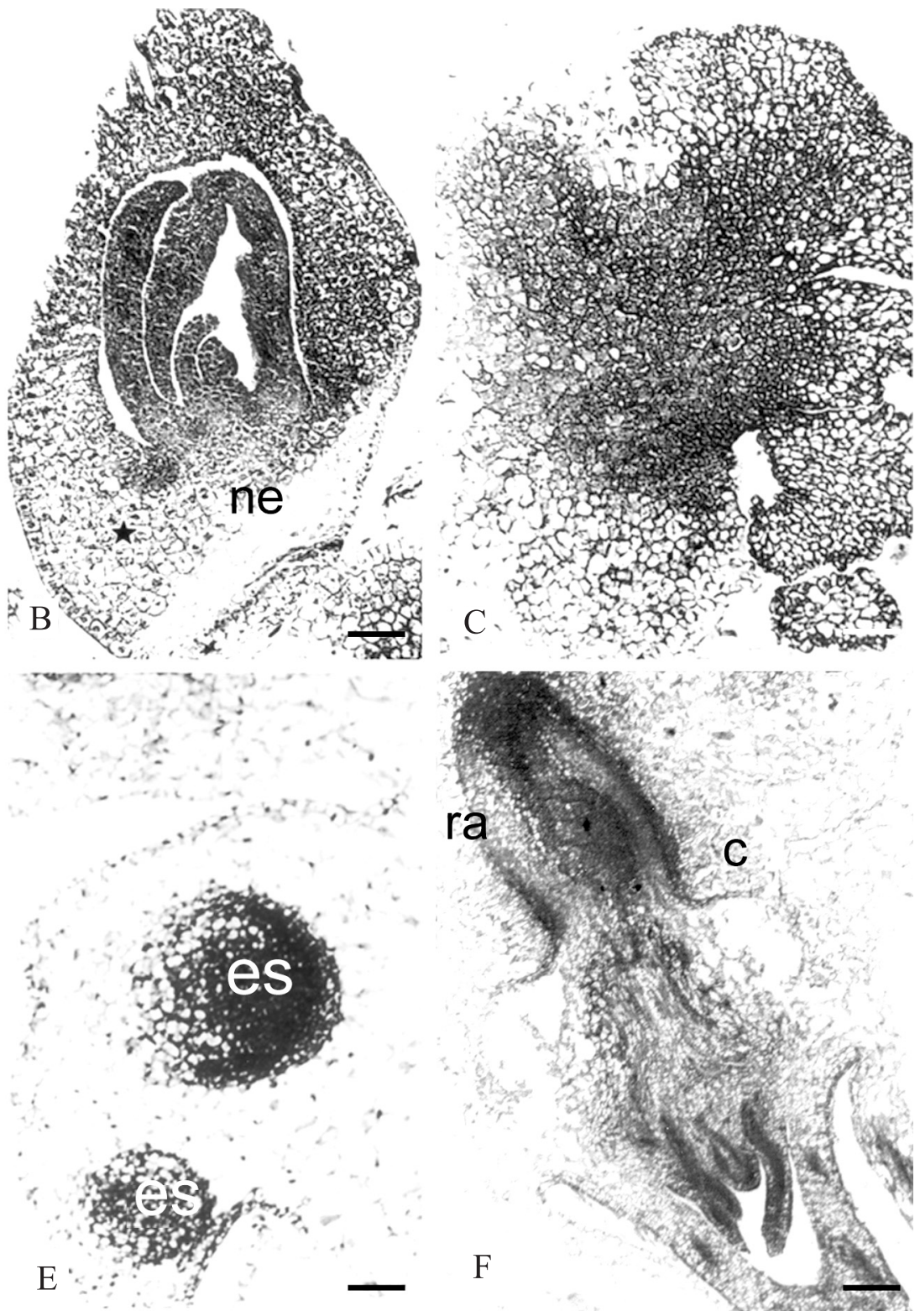

Figura 3. Análise morfológica (x50) do desenvolvimento in vitro de calos embriogênicos em embrião de semente madura de Urochloa brizantha cv. Marandu: A, fotomicrografia de secção longitudinal de embrião extraído de semente madura, em que se mostra o escutelo (e), o coleóptilo (c), a coleorriza (cr), primeira folha (pf), broto meristemático (bm), internó (in), e ápice da raiz (ra) - a barra corresponde a $4 \mathrm{~cm}$; B, embrião após três dias de cultivo em meio M1, em que são mostradas células volumosas $(\star$ ) e o nó do escutelo (ne) muito próximo - a barra corresponde a $2 \mathrm{~cm}$; , calos friáveis na periferia do escutelo após sete dias de cultivo, em que é mostrado grande número de células - a barra corresponde a $2 \mathrm{~cm}$; $\mathrm{D}$, estereomicrografia em que se mostra calo embriogênico compacto e branco ( $\star$ ), após 15 dias de cultivo - a barra corresponde a 1,8 cm; E, calos embriogênicos após 15 dias de cultivo em meio M1, em que se observam embriões somáticos (es) em desenvolvimento - a barra corresponde a $1 \mathrm{~cm} ; \mathrm{F}$, embriões somáticos após 20 dias de cultivo, em que se mostram o coleóptilo (c) e o ápice da raiz (ra) - a barra corresponde a $4 \mathrm{~cm}$. 
de embriões maduros de Panicum, Lu \& Vasil (1985) sugeriram que os embriões somáticos surgem da proliferação indiferenciada das células do parênquima e da região do escutelo, como observado em U. brizantha.

A descrição morfológica da formação de embriões somáticos em $U$. brizantha, realizada no presente trabalho, contribuirá para a manipulação das condições favoráveis de cultura de tecidos e transformação de plantas, para o desenvolvimento de estratégias de biotecnologia que poderão contribuir à ampliação da variabilidade genética de forragens no Brasil.

\section{Conclusões}

1. Embriões das sementes de Urochloa brizantha cv. Marandu são do tipo panicoide, e não apresentam epiblasto.

2. Embriões extraídos de sementes maduras de Urochloa brizantha cv. Marandu constituem explante adequado para a regeneração in vitro.

3. A formação de calos embriogênicos e embriões somáticos têm origem no escutelo e se estende para a periferia de embriões maduros de Urochloa brizantha cv. Marandu, nas condições experimentais usadas.

4. A regeneração in vitro de plântulas, a partir de embriões extraídos de sementes maduras de Urochloa brizantha cv. Marandu, dá-se por embriogênese somática a partir de células meristemáticas do escutelo.

\section{Agradecimentos}

À Dra. Diva Maria de Alencar Dusi, pelas discussões e leitura crítica do artigo. Ao Conselho Nacional de Desenvolvimento Científico e Tecnológico, pela concessão de bolsa de estudos à primeira autora e pelo financiamento parcial da pesquisa.

\section{Referências}

ALVES, E.R.; CARNEIRO, V.T.C.; ARAUJO, A.C.G. Direct evidence of pseudogamy in apomictic Brachiaria brizantha (Poaceae). Sexual Plant Reproduction, v.14, p.207-212, 2001.

ARAUJO, A.C.G.; MUKHAMBETZHANOV, S.; POZZOBON, M.T.; SANTANA, E.F.; CARNEIRO, V.T.C. Female gametophyte development in apomictic and sexual Brachiaria brizantha (Poaceae). Révue de Cytologie et de Biologie Végétales - Le Botaniste, v.23, p.13-28, 2000.
ARAUJO, A.C.G.; NÓBREGA, J.M.; POZZOBON, M.T.; CARNEIRO, V.T.C. Evidence of sexuality in induced tetraploids of Brachiaria brizantha (Poaceae). Euphytica, v.144, p.39-50, 2005.

ARAÚJO, S.A.C.; DEMINICS, B.B.; CAMPOS, P.R.S.S. Melhoramento genético de plantas forrageiras tropicais no Brasil. Archivos de Zootecnia, v.57, p.61-76, 2008.

BOTTI, C.; VASIL, I.K. The ontogeny of somatic embryos of Pennisetum americanum (L.) K. Schum. II. In cultured immature inflorescences. Canadian Journal of Botany, v.62, p.1629-1635, 1984.

CABRAL, G.B.; SANTANA, C.G.; CARNEIRO, V.T.C.; DUSI, D.M.A.; MATSUMOTO, K. Ocorrência de albinismo em embriogênese somática repetitiva em Brachiaria brizantha. Brasília: Embrapa Recursos Genéticos e Biotecnologia, 2006. Não paginado. (Embrapa Recursos Genéticos e Biotecnologia. Comunicado técnico, 155).

CABRAL, G.B.; SOUZA, R.W.; OLIVEIRA, L.; CARNEIRO, V.T.C.; DUSI, D.M.A. Indução de embriogênese somática em folhas de Brachiaria brizantha. Brasília: Embrapa Recursos Genéticos e Biotecnologia, 2008. 5p. (Embrapa Recursos Genéticos e Biotecnologia. Boletim de pesquisa e desenvolvimento, 227).

CAMPOS, J.M.S. de; CALDERANO, C. de A.; PEREIRA, A.V.; DAVIDE, L.C.; VICCINI, L.F.; SANTOS, M. de O. Embriogênese somática em híbridos de Pennisetum sp. e avaliação de estabilidade genômica por citometria. Pesquisa Agropecuária Brasileira, v.44, p.38-44, 2009.

CARNEIRO, V.T.C.; DUSI, D.M.A. Apomixia: em busca de tecnologias de clonagem de plantas por sementes. Biotecnologia Ciência e Desenvolvimento, v.25, p.36-42, 2002.

INSTITUTO BRASILEIRO DE GEOGRAFIA E ESTATÍSTICA. Sistema IBGE de recuperação automática: efetivos dos rebanhos. 2006. Disponível em: <http://www.sidra.ibge.gov.br/bda/pecua/>. Acesso em: 14 jun. 2010.

JIMENEZ, V.M. Involvement of plant hormones and plant growth regulators on in vitro somatic embryogenesis. Plant Growth Regulation, v.47, p.91-110, 2005.

KARIA, C.T.; DUARTE, J.B.; ARAÚJO, A.C.G. de. Desenvolvimento de cultivares do gênero Brachiaria (trin.) Griseb. no Brasil. Planaltina: Embrapa Cerrados, 2006. 57p. (Embrapa Cerrados. Documentos, 163).

LAMB, C.R.C.; MILACH, S.C.K.; PASQUALI, G.; BARRO, R.S. Embriogênese somática e regeneração de plantas a partir de embrião maduro de aveia. Pesquisa Agropecuária Brasileira, v.37, p.123-130, 2002.

LENIS-MANZANO, S.J. Desenvolvimento de um método de transformação genética de Brachiaria sp., por bombardeamento de partículas. 1998. 131p. Dissertação (Mestrado) - Universidade de Brasília, Brasília.

LU, C.-Y; VASIL, I.K. Histology of somatic embryogenesis in Panicum maximum (Guinea grass). American Journal of Botany, v.72, p.1908-1913, 1985. 
MURASHIGE, T.; SKOOG, F. A revised medium for rapid growth and bioassays with tobacco tissue cultures. Physiologia Plantarum, v.15, p.473-497, 1962.

O'HARA, J.F.; STREET, H.E. Wheat callus culture: the initiation, growth and organogenesis of callus derived from various explant sources. Annals of Botany, v.42, p.1029-1038, 1978.

OLIVEIRA, L.; DUSI, D.M.A.; LACERDA, A.L.M.; CARNEIRO, V.T.C.; CABRAL, G.B. Efeito de meios, pH e tratamento osmótico na transformação genética de suspensão celular e regeneração de plantas de Brachiaria brizantha cv. Marandu. Brasília: Embrapa Recursos Genéticos e Biotecnologia, 2008. 8p. (Embrapa Recursos Genéticos e Biotecnologia. Boletim de pesquisa, 228).

OZIAS-AKINS, P. Apomixis: developmental characteristics and genetics. Critical Reviews in Plant Sciences, v.25, p.199-214, 2006.

PINHEIRO, A.A.; POZZOBON, M.T.; VALLE, C.B. do; PENTEADO, M.I.O.; CARNEIRO, V.T.C. Duplication of the chromosome number of diploid Brachiaria brizantha plants using colchicine. Plant Cell Reports, v.19, p.274-278, 2000.

ROY, A.T.; DE, D.N. Tissue culture and plant regeneration from immature embryo explants of Calotropis gigante a (Linn.). Plant Cell, Tissue and Organ Culture, v.20, p.229-233, 1990.

SILVEIRA, E.D.; RODRIGUES, J.C.M.; CABRAL, G.B.; LEITE, J.A.; COSTA, S.S.; CARNEIRO, V.T.C. Evaluation of exogenous promoters for use in Brachiaria brizantha transformation. Journal of Plant Biotechnology, v.5, p.87-93, 2003.

SHIRASUNA, R.T. Lista de espécies da flora do Brasil: /Urochloa/ /humidicola/ (Rendle) Morrone \& Zuloaga//. Rio de Janeiro: Jardim Botânico, 2010. Disponível em: <http://floradobrasil.jbrj. gov.br/2010/FB087091/>/. Acesso em: 21 jun. 2010.

TOHME, J.; PALACIOS, N.; LENIS, S. ROCA, W. Applications of biotechnology to Brachiaria. In: MILES, J.W.; MAASS, B.L.; VALLE, C.B. do (Ed.). Brachiaria: biology, agronomy and improvement. Cali: CIAT; Campo Grande: Embrapa-CNPGC, 1996. p.196-204. (CIAT. Publication, 259).

TUCKER, M.R.; KOLTUNOW, A.M.G. Sexual and asexual (apomictic) seed development in flowering plants: molecular, morphological and evolutionary relationships. Functional Plant Biology, v.36, p.490-504, 2009.

VALLE, C.B. do; BONATO, A.L.V.; PAGLIARINI, M.S.; RESENDE, R.M.S.; JANK, L. Apomixia e sua utilização no melhoramento de Brachiaria. In: CARNEIRO, V.T. de C.; DUSI, D.M. de A. (Ed.). Clonagem de plantas por sementes: estratégias de estudo da apomixia. Brasília: Embrapa Recursos Genéticos e Biotecnologia, 2004. p.47-66.

VASIL, I.K. Molecular genetic improvement of cereals: transgenic wheat (Triticum aestivum L.). Plant Cell Reports, v.26, p.1133-1154, 2007.

VASIL, I.K. Progress in the regeneration and genetic manipulation of cereal crops. Bio/Technology, v.6, p.397-402, 1988.

VASIL, I.K. The story of transgenic cereals: the challenge, the debate, and the solution: a historical perspective. In Vitro Cellular and Developmental Biology-Plant, v.41, p.577-583, 2005.

VASIL, V.; VASIL, I.K. Characterization of an embryogenic cell suspension culture derived from cultured inflorescences of Pennisetum americanum (Pearl Millet, Gramineae). American Journal of Botany, v.69, p.1441-1449, 1982.

YU, Y.; WANG, J.; ZHU, M.L.; WEI, Z.M. Optimization of mature embryo-based high frequency callus induction and plant regeneration from elite wheat cultivars grown in China. Plant Breeding, v.127, p.249-255, 2008.

ZHANG, W.-J.; DONG, J.-L.; LIANG, B.-G.; JIN, Y.-S.; WANG, T. Highly efficient embryogenesis and plant regeneration of tall fescue (Festuca arundinacea Schreb.) from mature seed-derived calli. In Vitro Cellular and Developmental Biology-Plant, v.42, p.114-118, 2006.

$\overline{\text { Recebido em } 22 \text { de setembro de } 2009 \text { e aprovado em } 9 \text { de abril de } 2010}$ 